\title{
Complicated malaria symptoms associated with Plasmodium vivax among patients visiting health facilities in Mendi town, Northwest Ethiopia
}

Yohannes Demissie and Tsige Ketema*

\begin{abstract}
Background: Malaria is still a major health problem in some parts of the world. Plasmodium falciparum is the common pathogenic parasite and is responsible for majority of malaria associated deaths. Recently the other benign parasite, $P$. vivax, is reported to cause life threatening severe malaria complications. Thus, this study was aimed to assess incidence of severe malaria symptoms caused by P. vivax parasite in some malaria endemic areas of Ethiopia.

Materials and methods: Presumptive malaria patients (all age groups) seeking medication at the selected health facilities in Mendi town, Northwest Ethiopia, were recruited for the study. Socio-demographic, clinical and parasitological characteristics were assessed following standard procedures. Data was analyzed using descriptive statistics, chi-square test and relative risk.

Results: Of the 384 patients enrolled in the study for P. vivax mono-infection, 55 (14.3\%) of them were fulfilled at least one of the WHO criteria for severe malaria indicators. Some of these clinical manifestations were: prostration 14 (25. $45 \%)$, persistent vomiting 9 (16.36\%), respiratory distress 6 (10.9\%), hypoglycemia 5 (9.1\%), hyperpyrexia 8 (14.5\%), and severe anemia 13 (23.63\%). Differences in parasite load did not affect the frequency of some severe malaria symptoms. However, severe anemia, prostration, and persistent vomiting were significantly affected $(P<0.05)$ by relatively higher load of parasitemia, ( $\mathrm{OR}=3.8,95 \% \mathrm{Cl}, 1.1-13.7 ; \mathrm{OR}=4.4,95 \% \mathrm{Cl}, 1.4-13.9$; and $\mathrm{OR}=7,95 \% \mathrm{Cl}, 1.8-27$. 4) respectively.

Conclusion: P.vivax associated severe malaria symptoms observed in this study is supportive evidence for the notion that P.vivax is no longer benign parasite but rather virulent. Thus, to meet international and regional targets of malaria eradication, a holistic prevention and control approaches should be designed.
\end{abstract}

Keywords: Hemoglobin, Hypoglycemia, P. vivax, Respiratory distress, Severe malaria

Abbreviations: ARDS, Acute respiratory distress syndromes; Cl, Confidence interval; COX-2, Cyclooxygenase-2; CSA, Central Statistical Agency; Glu, Blood glucose; Hb, Hemoglobin; IRBC, Infected red blood cells; OR, Odd ratio; $\mathrm{RR}$, Relative risk

\footnotetext{
* Correspondence: tsigeketema@gmail.com

Department of Biology, College of Natural Sciences, Jimma University, Jimma,

Ethiopia
} 


\section{Background}

Malaria is one of the most important health problems in developing countries. It is estimated that about half of the world's population are at risk of malaria [1, 2]. P. falciparum and $P$. vivax have worldwide distribution, with $P$. falciparum being the more pathogenic. Few years back, it was indicated that about 1-3 million mortality per year, mainly in children and pregnant women, are due to severe malaria caused by $P$. falciparum [3]. However, according to the latest report released by WHO [4] there were an estimated 584,000 deaths globally. The same report showing reduction of malaria mortality rates among children in Africa by an estimation of $47 \%$ globally since 2000 and by $54 \%$ in the WHO African Region [4].

In Ethiopia malaria is unstable and seasonal. This is because of the country's heterogeneous topography and climatic factors $[5,6]$. Areas at altitudes between 1600 and $2000 \mathrm{~m}$ above sea level (masl) are epidemic-prone hypo-endemic zones of malaria [7]. However, malaria epidemics are expanding to areas as high as 2500 masl [8]. On the other hand, although $P$. vivax is a rare parasite in most parts of Africa, it is an important parasite in Ethiopia. In some areas of the country the prevalence rate even exceeds $70 \%$ of total malaria infections. This was previously reported due to the high Duffy positivity trait of most population of Ethiopia, but recently contradictory reports are coming [9-11]. In addition, chloroquine resistance pattern of $P$. vivax parasite is increasing in the country [12]. Recently severe life threatening malaria symptoms, frequently associated with P. falciparum, has been reported from Asia, South America and Africa for $P$. vivax [13-18]. Thus, the current study was aimed to assess incidence of severe malaria symptoms due to $P$. vivax infection in one of malaria endemic areas of Ethiopia.

\section{Methods}

\section{Description of the study area}

A cross sectional study was conducted in Mendi Town, located $567 \mathrm{~km}$ Northwest of Addis Ababa, the capital city of Ethiopia (Fig. 1). Geographically the study site is located at latitude and longitude of $9^{\circ} 48^{\prime} \mathrm{N} 35^{\circ} 6^{\prime} \mathrm{E}$ and the mean altitude of 1538 masl. Annual rainfall ranged from 900 to $1500 \mathrm{~mm}$ and main rainy season is from May to October. The mean annual maximum temperature of the area is about $32{ }^{\circ} \mathrm{C}(25-32)$. The two principal parasites of malaria infection in the study area are $P$. falciparum and $P$. vivax. The main vector in the study area is A. arabiensis. Based on the 2007 Census conducted by the Central Statistical Agency (CSA) of Ethiopia, this town has a total population of 28,485 of whom 14,385 are males and 14,100 females [19].

\section{Study population}

The study participants were all presumptive malaria patients seeking medication at the health center and clinic in Mendi town, during the study period from September, 2014 to June, 2015 and those who had symptoms of malaria infection. The inclusion criteria used were any patient positive for $P$. vivax mono-infection (microscopy confirmed), without any chronic illness, without prior medication for the current illness, having clinical symptoms such as fever, chills, malaise, headache, vomiting,

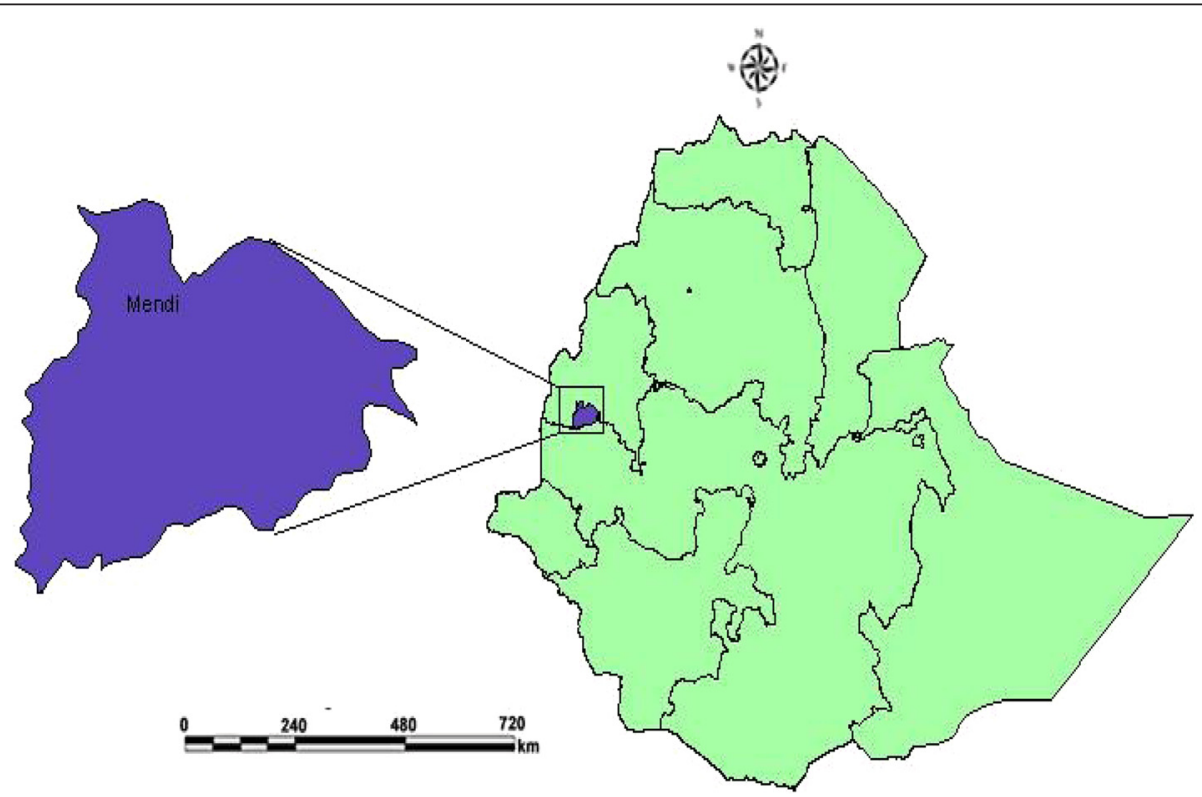

Fig. 1 Map of the study site 
history of fever for about $48 \mathrm{~h}$ before admission, and volunteer to participate in the study. Accordingly, a total of 384 patients who fulfilled the inclusion criteria were included in the study.

\section{Data collection}

Clinical and demographic data were collected using predesigned case record form by trained health professionals working in the two health facilities. Clinical symptoms such as fever, headache, diarrhea, hyperpyrexia, hemoglobunria, persistent vomiting, impaired consciousness, convulsion, respiratory distress, persistent vomiting, hypotension, anorexia, nausea, and rigor were assessed following criteria set on guideline for malaria diagnosis and treatment [20]. Body temperature of each patient was measured using digital thermometer.

Patients with at least one symptom of severe malaria complications set by World Health Organization (WHO) were classified as severe $P$. vivax cases [20]. Preliminary screening of the blood smears for P.vivax was done by two experienced laboratory technician working in the two health facilities. To ensure data quality, the positive slides were further confirmed by certified senior laboratory technician at Jimma University. Fortunately there were no difference in their reading and the original record was used for analysis. Detailed description of the blood collection and smear preparation is as follows: a drop of blood sample was collected on clean glass slide from lancet pricked finger to prepare thin and thick blood smears in duplicate per patient for microscopic examination. Thick and thin blood smears were stained with $3 \%$ Giemsa ( $\mathrm{pH}=7.2$, for $45 \mathrm{~min})$, while thin smears were fixed in methanol before Giemsa staining. Malaria parasite was identified by observation of the smears and the morphological appearance of the parasite in the infected red blood cells (RBCs) using $\times 100$ microscope objective. Parasite load was calculated after counting asexual parasites per 200 white blood cells (WBC), assuming mean WBC count of 8000 count/ $\mu \mathrm{L}$ using the following formula:

Parasite load $/ \mu \mathrm{L}=\frac{\text { Number of observed asexual parasites } \times 8000 \mathrm{WBC} \text { count } / \mu \mathrm{L}}{200 \mathrm{WBCs}}$

The degree of parasitaemia was graded as mild, moderate, and severe, when a count $(\mathrm{x})$ is between 1 and 999 parasite $/ \mu \mathrm{L}, 1000-9999 / \mu \mathrm{L},>10,000 / \mu \mathrm{L}$, respectively [21].

From the pricked finger, some drops of blood samples were taken for quantification of levels of blood glucose (Glu) (Senso Card Hungary) and hemoglobin (Hb) (Hemo$\mathrm{cue}^{\mathrm{Tn}}$, haemoglobino meter, Angelholm, Sweden, $\mathrm{Hb} 301$ ). The patient was considered anemic when $\mathrm{Hb}$ level is $<11 \mathrm{~g} /$ $\mathrm{dL}$ (children) and $<13 \mathrm{~g} / \mathrm{dL}$ (adult male) and $<12 \mathrm{~g} / \mathrm{dL}$ dult female). Further, level of anemia was classified as severe, moderate and mild, when $\mathrm{Hb}$ level is $<5 \mathrm{~g} / \mathrm{dL}$, between 5 and $8 \mathrm{~g} / \mathrm{dL}$, and between 8 and $11 \mathrm{~g} / \mathrm{dL}$, respectively [20]. Lower blood glucose (hypoglycemia) was considered when blood glucose concentration was $<40 \mathrm{mg} / \mathrm{dL}$. Hyperpyrexia was considered when body temp is $\geq 40{ }^{\circ} \mathrm{C}$. All participants were treated with Chloroquine sulfate as soon as the blood sample was drawn and found positive for P.vivax following National Guideline for Malaria Diagnosis and Treatment [22].

\section{Data analysis}

Data was analyzed using SPSS statistical software (Version 20.0. Armonk, NY: IBM Corp). Descriptive statistic was used for analysis of some clinical, demographic and parasitological data. Associations between variables were computed using Pearson correlation. Responses were compared using chi-square test, and relative risk was used to assess strength of association between variables in groups. In all analysis, significance level was considered at $95 \%$ confidence interval $(\mathrm{CI})$.

\section{Results}

Prevalence of malaria in the study area

The trend of malaria cases showed an irregular declining pattern. However, the 5 years prevalence report (20102014) of the two health facilities showed that, the number of malaria infected patients was still higher (Fig. 2).

Of the total 14, 844 individuals (8751 females and 6093 males) seeking medication at the two health facilities, blood samples were collected from 4813 suspected malaria cases. Accordingly, 1434 (818 males and 616 females) were found positive for malaria infection. Among the positive cases, A total of 533 (37.2\%) and 851 (59.3 \%) were infected with $P$. vivax and $P$. falciparum, respectively, while, $50(3.5 \%)$ were due to mixed infection (P. vivax and P. falciparum). The highest peak infection for $P$. falciparum and $P$. vivax was observed in November followed by October (Fig. 3).

\section{Socio-demographic and clinical characteristics of the study participants}

In the current study, a total of 384 patients that fulfilled the inclusion criteria were clinically diagnosed and enrolled in the study. Prevalence of malaria among male and females patients were $52.6 \%(n=$ $202)$ and $47.4 \%(n=182)$, respectively. Among different age groups, the distribution of malaria infection with respect to sex was almost similar, except in those aged less than 5 years, where the infection was higher among male population of the same age. In terms of sex, male malaria patients $(n=202,52.6 \%)$ were significantly higher than that of females $\left(\chi^{2}=\right.$ 64.2, $P<0.05)$.

Median age of the study participants was 14 years (1 month to 60 years). Mean body temperature and blood 


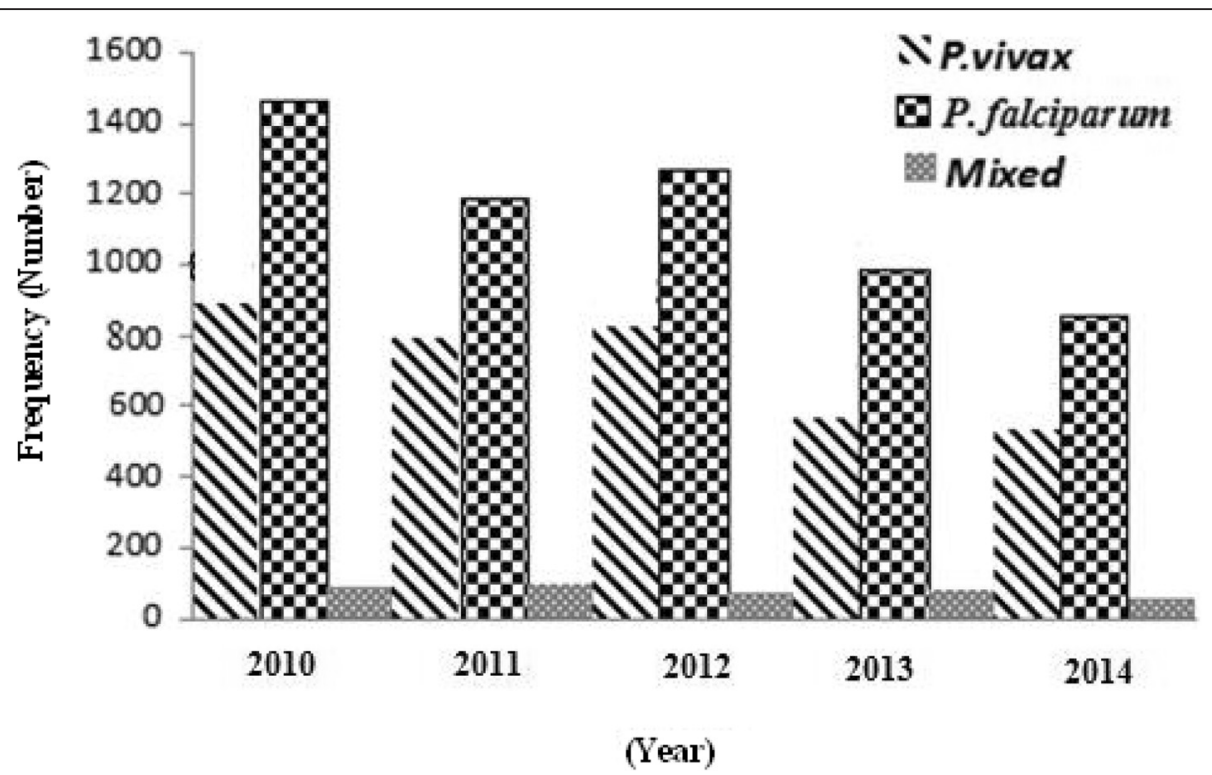

Fig. 2 Malaria cases among patients in Mendi town, Oromia, Northwest Ethiopia, 2010-2014

glucose levels of the study participants were $37.89{ }^{\circ} \mathrm{C}$ (35.5 to 40.8 ) and $104.4 \mathrm{mg} / \mathrm{dL}$ (36.8 to 180$)$, respectively. Also, the level of $\mathrm{Hb}$ and geometric mean parasite counts were $12.4 \mathrm{~g} / \mathrm{dL} \quad(4.3-17.8)$ and 3745 parasite $/ \mu \mathrm{L}$ (280-31,600), respectively. The observed anemic cases were 115 (29.9\%) (Table 1).

\section{Status of uncomplicated malaria symptoms in P. vivax} mono-infected patients

Uncomplicated malaria symptoms observed in the current study were headache 255 (66.4\%), aching 231
(60.2\%), chills 225 (58.6\%), vomiting 179 (46.6\%), rigor 152 (39.6\%), shivering 151 (39.3\%), cramp 150 (39.1\%), nausea 147 (38.3\%), anorexia 61 (15.9\%) and diarrhea 22 (5.72 \%) (Table 2). At the time of admission, about 179 (46.6\%) and 22 (5.7 \%) of the patients had vomiting, and diarrhea, respectively. But, none had symptoms of splenomegaly and hepatomegaly. Although most patients, 360 (93.8\%) had a history of fever for the past $48 \mathrm{~h}$, only $227(59.1 \%)$ were febrile or had axillary temperature $\geq 37.5{ }^{\circ} \mathrm{C}$ (Table 2).

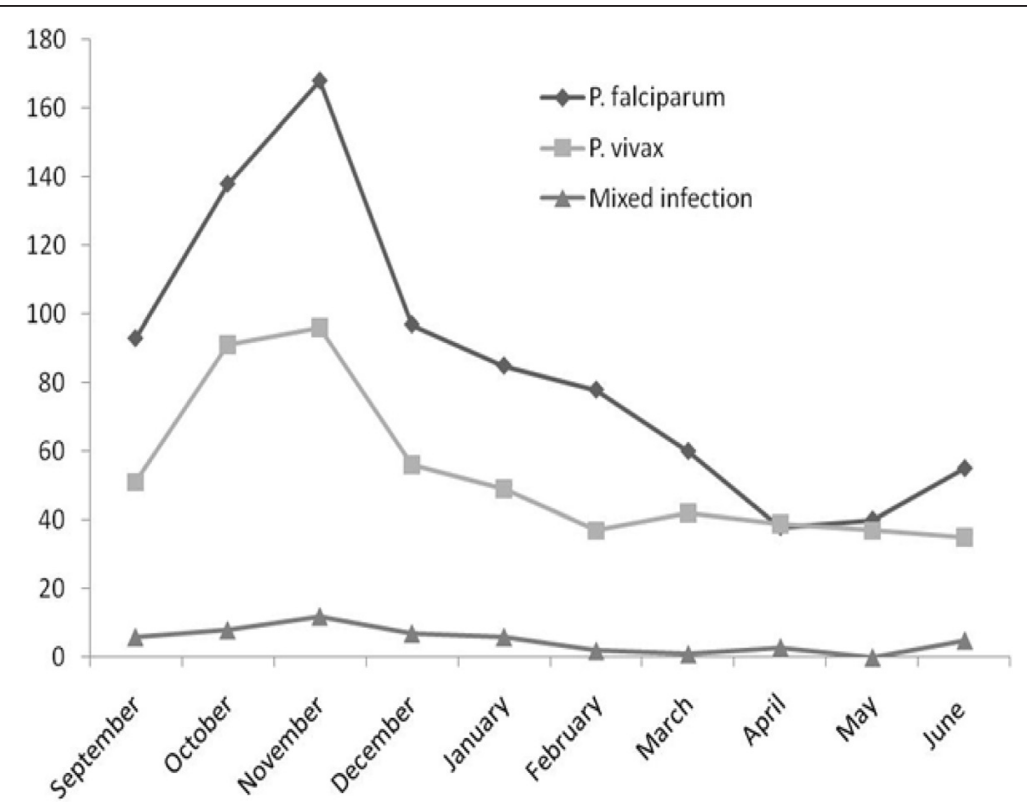

Fig. 3 Confirmed malaria cases during the study period at health facilities in Mendi town, Northwest Ethiopia, 2014/15 
Table 1 Clinical and demographic characteristic of $P$. vivax malaria infected patients, at Mendi town, Northwest Ethiopia

\begin{tabular}{ll}
\hline Clinical features & Frequency \\
\hline $\begin{array}{l}\text { Age (years) } \\
\text { Median age }\end{array}$ & $14(1$ month to 60 years $)$ \\
$\cdot<5$ & $101(26.3 \%)$ \\
$\cdot 5-14$ & $97(25.26 \%)$ \\
$\cdot>14$ & $186(48.4 \%)$ \\
Sex & \\
$\cdot$ Male & $202(52.6 \%)$ \\
$\cdot$ Female & $182(47.4 \%)$ \\
Temperature & $37.89\left({ }^{\circ} \mathrm{C}\right)$ \\
Febrile cases & $329(85.7 \%)$ \\
Blood glucose level & $109.89(\mathrm{mg} / \mathrm{dL})$ \\
Hemoglobin level & $12.4(\mathrm{~g} / \mathrm{dL})$ \\
Anemic cases & $115(29.9 \%)$ \\
Geometric mean parasite count & $3745(\mathrm{parasite} / \mathrm{\mu L})$ \\
\hline
\end{tabular}

\section{Incidence of severe malaria symptoms}

Severe malaria symptoms were observed in 55 (14.32 \%) patients infected with $P$. vivax mono-infection. A total of $36(65.5 \%)$ patients fulfilled at least one of the WHO criteria for severe malaria symptoms while 19 (34.5\%) had two or more overlapping severity indicators. of the later cases, $12(63.2 \%)$ had two combined symptoms, 5 (26.3\%) had three combined symptoms and the remaining 2 (10.5\%) had four combined symptoms.

Some of these clinical manifestations were: prostration $n=14(25.45 \%)$, persistent vomiting $n=9$ (16.36 \%), respiratory distress $n=6$ (10.9\%), hypoglycemia $n=5$

Table 2 Frequencies of uncomplicated symptoms in $P$. vivax malaria infected patients, Mendi town, Northwest Ethiopia

\begin{tabular}{ll}
\hline Symptoms of uncomplicated malaria & Frequency (\%) \\
\hline Headache & $255(66.4)$ \\
Diarrhea & $22(5.7)$ \\
Chills & $225(58.6)$ \\
Aching & $231(60.2)$ \\
Vomiting & $179(46.6)$ \\
Anorexia & $61(15.9)$ \\
Nausea & $147(38.3)$ \\
Rigor & $152(39.6)$ \\
Shivering & $151(39.3)$ \\
Cramp & $150(39.1)$ \\
History of fever for about $48 \mathrm{~h}$ & $360(93.8)$ \\
Fever at time of enrollment & $227(59.1)$ \\
(Febrile) body temperature $\geq 37.5^{\circ} \mathrm{C}$ & \\
Splenomegaly & $0(0)$ \\
Hepatomegaly & $0(0)$ \\
\hline
\end{tabular}

(9.1\%), hyperpyrexia $n=8(14.5 \%)$ and severe anemia $n$ $=13(23.63 \%)$. Major severe malaria symptoms observed were prostration, and severe anemia, in combination with other symptoms including persistent vomiting, hyperpyrexia, and hypoglycemia. However, none had signs of confusion, coma, hemoglobinuria or discoloration of urine and hypotension (Table 3). None of the participants died during the study period.

Most severe malaria manifestations were presented in children less than 5 years. To mention, severe anemia was observed in 12 children aged less than 5 years and 2 children aged between 5 and 14, but none among adults. These three severe symptoms were higher among children under 5 years than other age groups (Table 4).

From the analysis made on association between parasite load and severe malaria symptoms, it was observed that differences in parasite load did not affect the occurrence of respiratory distress, hyperpyrexia, and hypoglycemia. Significant differences were not observed $(P>0.05)$ with respect to relative risk (RR) of $P$. vivax infected patients of different parasite load (between 1000 and 9999, and $\geq 10,000$ ). However, severe anemia, prostration, and persistent vomiting were significantly associated $(P<0.05)$ with severe parasitemia $(\geq 10,000$ parasite/ $\mu \mathrm{L}), \quad[(\mathrm{OR}=3.8,95 \% \mathrm{CI}, 1.1-13.7 ; \mathrm{OR}=4.4,95 \% \mathrm{CI}$, 1.4-13.9; and $\mathrm{OR}=7.95 \% \mathrm{CI}, 1.8-27.4)$, respectively (Table 5).

\section{Discussion}

The overall prevalence of malaria during the study period $(2014 / 15)$ was $29.8 \%$, (declined by $3.3 \%$ from the $33.1 \%$ prevalence documented in 2005 by the two local health facilities 2013) (Unpublished data). The overall prevalence of malaria observed during the study period was slightly lower than the recent report from southern part of Ethiopia (31.9\%) [16] and much lower than report from Nigeria (81.9\%) [23]. The possible

Table 3 Clinical manifestations of severe malaria symptoms in patients $(n=55)$ infected with P. vivax, Mandi town, Northwest Ethiopia

\begin{tabular}{ll}
\hline Clinical symptom & Frequency (\%) \\
\hline Severe anemia & $13(23.63)$ \\
Respiratory distress & $6(10.9)$ \\
Prostration & $14(25.45)$ \\
Hyperpyrexia & $8(14.5)$ \\
Persistent vomiting & $9(16.36)$ \\
Hypoglycemia & $5(9.1)$ \\
Comma & $0(0)$ \\
Convulsion & $0(0)$ \\
Hypotension & $0(0)$ \\
Hemoglobinuria & $0(0)$ \\
\hline
\end{tabular}


Table 4 Incidence of severe malaria symptoms among different age groups of patients infected with $P$. vivax malaria, at Mandi town, Northwest Ethiopia

\begin{tabular}{llll}
\hline Clinical features & \multicolumn{3}{l}{ Age (year) } \\
\cline { 2 - 4 } & $<5$ & $5-14$ & $>14$ \\
\hline Respiratory distress & $3(57.9 \%)$ & $2(31.6 \%)$ & $1(10.5 \%)$ \\
Hyperpyrexia & $5(62.5 \%)$ & $1(12.5 \%)$ & $2(25 \%)$ \\
Persistent vomiting & $5(55.5 \%)$ & $3(33.3 \%)$ & $1(10 \%)$ \\
Severe anemia & $11(84.6 \%)$ & $2(15.4 \%)$ & $0(0)$ \\
Prostration & $8(57.14 \%)$ & $4(28.57 \%)$ & $2(14.28 \%)$ \\
Hypoglycemia & $3(60 \%)$ & $2(40 \%)$ & $0(0)$ \\
\hline
\end{tabular}

explanation for the observed discrepancy could be due to the intense and diverse malaria control strategies undertaken in most parts of the country [22].

$P$. vivax mono-infection has been associated with severe and fatal disease in endemic areas [13, 24, 25]. The observed severe malaria symptoms in this study (14.3\%) was almost similar to reports from southern Ethiopia $(13.67 \%)$ and Tertiary care center of central India among hospitalized patients $(17.2 \%)$ due to $P$. vivax malaria $[16,18]$, but lower than report from Eastern Sudan's New Halfa Hospital (27.8 \%) [26]. The most commonly encountered severe malaria manifestations of P.vivax mono infection in this study were prostration, followed by severe anemia, persistent vomiting, hyperpyrexia, respiratory distress, and hypoglycemia. As observed in our study, severe malaria symptoms commonly detected in $P$. vivax infected patients is severe anemia [24]. This could be due to continuous presence of the parasite in liver as hypnozoite stage, infecting and destroying young RBCs [25]. Also, for every infected RBC destroyed during $P$. vivax infection, 32 noninfected RBCs are removed from the circulation, compared to the loss of $8 \mathrm{RBCs}$ for every infected erythrocyte in P. falciparum malaria [27]. Other assumption is that anemia might occur as a result of rigor inflammatory reactions [28] and phagocytosis of non-parasitized red blood cells, increased splenic clearance, and dyserythropoiesis in bone marrow [29]. To this effect severe anemia caused by $P$. vivax is responsible for $87 \%$ of severe diseases compared to $73 \%$ of severe malaria complications that occur due to P. falciparum [13]. In this study, significant number of severe anemia patients was children aged less than 5 years. The high susceptibility of young children to severe anemia could be due to relatively faster attainment of immunity to $P$. vivax than to P. falciparum [30-32].

Frequency of respiratory distress due to $P$. vivax mono infection observed in this study $(10.9 \%)$ was higher than report from India (6.8 \%) [18], but comparable with other report from adults living in malaria-endemic areas in Bikaner, Northwestern India (10 \%) [14]. The possible mechanism of pathogenesis of respiratory distress in $P$. vivax malaria has been proposed to be severe alveolar capillary dysfunction like in P. falciparum [33]. This is evidenced by the comparable clinical manifestations of acute respiratory distress syndromes (ARDS) in P. vivax and $P$. falciparum infected patients [34-36].

Most of these symptoms are largely attributed to production of various cytokines such as TNF- $\alpha$ produced in response to the parasite and toxin products released during rupture of infected RBCs [37]. Also, hemozoin released from infected RBCs (iRBCs) leading to the release of pro-inflammatory cytokines that inturn induce COX-2 (cyclooxygenase-2) up-regulating prostaglandins leading to the induction of fever [38,39]. As there is an evidence for rigor inflammatory reactions due to proinflammatory response and cytokines activation during P. vivax infection [28], the hyperpyrexia and persistent vomiting observed in this study could be due to the intense inflammatory reaction caused by $P$. vivax.

Differences in parasite load did not affect the incidence of severe malaria symptoms among assessed patients. This was in consistence with earlier report made by Price et al. [40], which explained that $P$. vivax is capable of inducing fever at levels of parasitemia lower than those causing fever in P. falciparum infection [40]. WHO also reported that in western Thailand, a region of low endemicity, the pyrogenic density for $P$. vivax was 180 parasites $/ \mu \mathrm{L}$ compared to 1000 parasites $/ \mu \mathrm{L}$ observed in $P$. falciparum infection [41]. This is mainly because of the fact that $P$. vivax has a tendency to achieve

Table 5 Strength of association between parasitemia and severe malaria indicators in patients infected with P. vivax malaria, Mandi town, Northwest Ethiopia, 2014/15

\begin{tabular}{|c|c|c|c|c|c|c|c|c|c|c|c|c|}
\hline \multirow[t]{3}{*}{ Parasite load } & \multicolumn{12}{|c|}{ Sever malaria indicators (\%) } \\
\hline & \multicolumn{2}{|c|}{ Severe anemia } & \multicolumn{2}{|c|}{ Respiratory distress } & \multicolumn{2}{|c|}{ Prostration } & \multicolumn{2}{|c|}{ Persistent vomiting } & \multicolumn{2}{|c|}{ Hyperpyrexia } & \multicolumn{2}{|c|}{ Hypoglycemia } \\
\hline & Yes & No & Yes & No & Yes & No & Yes & No & Yes & No & Yes & No \\
\hline 1000-9999 & $9(3.4)$ & $258(96.6)$ & $4(1.5)$ & $263(98.5)$ & $10(3.7)$ & $257(96.3)$ & $5(1.9)$ & $262(98.1)$ & $5(1.9)$ & $262(98.1)$ & $4(1.5)$ & $263(98.5)$ \\
\hline$\geq 10,000$ & $4(11.8)$ & $30(88.2)$ & $2(5.9)$ & $32(94.1)$ & $4(12.1)$ & $29(85.3)$ & $4(11.8)$ & $30(88.2)$ & $3(8.57)$ & $32(94.1)$ & $1(2.9)$ & $33(97.1)$ \\
\hline Relative risk (RR) & \multicolumn{2}{|c|}{$\begin{array}{l}\mathrm{RR}=0.26 \\
(95 \% \mathrm{Cl}, 0.076-0.9) \\
P=0.034\end{array}$} & \multicolumn{2}{|c|}{$\begin{array}{l}\mathrm{RR}=0.24 \\
(95 \% \mathrm{Cl}, 0.043-1.38) \\
P=0.11\end{array}$} & \multicolumn{2}{|c|}{$\begin{array}{l}\mathrm{RR}=0.28 \\
(95 \% \mathrm{Cl}, 0.08-0.95) \\
P=0.042)\end{array}$} & \multicolumn{2}{|c|}{$\begin{array}{l}\mathrm{RR}=0.14 \\
(95 \% \mathrm{Cl}, 0.036-0.56) \\
P=0.005\end{array}$} & \multicolumn{2}{|c|}{$\begin{array}{l}\mathrm{RR}=0.19 \\
(95 \% \mathrm{Cl}, 0.045-0.86) \\
P=0.03\end{array}$} & \multicolumn{2}{|c|}{$\begin{array}{l}\mathrm{RR}=1.9 \\
(95 \% \mathrm{Cl}, 0.2-18.4) \\
P=0.54\end{array}$} \\
\hline
\end{tabular}


and maintain lower density parasitemia as it only invades young RBCs [42]. In addition, patients with $P$. vivax infections also tend to present all parasite stages that could be visible on the peripheral blood film $[4,43]$. Hypothesis given for the lower parasitemia caused by $P$. vivax may be due to the presence of the same parasite in haemopoietic tissue than in the vascular sinus [35]. Thus, parasite load of $P$. vivax in peripheral blood could expand rigorously without its detection [44].

Naturally, $P$. vivax causes an acute febrile illness with no complications or death. However, recently reports on complications due to $P$. vivax are globally increasing [29, $45,46]$. The exact causes of changes in the clinical profile of $P$. vivax infection are uncertain. It is assumed that, it may be due to genetic alterations of the parasite or change in vector and its biting habits, indiscriminate use of anti-malarial drugs, delayed treatment, or due to declining efficacy of chloroquine or rise in chloroquineresistant $P$. vivax strains [47-49]. In addition, prolonged existence of hypnozoite reservoir in patient's liver could cause recurrent infection even after patients successfully treated [50]. The increasing evidence on severe malaria complications associated with $P$. vivax has implication on the current global target of malaria eradication. Using knowledge and long experience accumulated over periods on $P$. falciparum, all concerned bodies including policy makers, researchers and others working in the same field should characterize clinical epidemiology and economic burden of $P$. vivax in different geographical areas for better management of burdens due to P.vivax infection.

\section{Study limitation}

The lack of confirmation of absence of mixed infection due to P.vivax and P.falciparium using PCR is a major limitation of this study.

\section{Conclusion}

Some severe malaria complications such as prostration, severe anemia, respiratory distress, hyperpyrexia and persistent vomiting were observed in $P$. vivax monoinfected individuals. This strengthens the fact that parasite. $P$. vivax is no longer benign. Therefore, to meet the set international targets for reduction of malarial morbidity and mortality, and regional elimination of P.vivax infection, concerned bodies should no longer neglect this parasite.

\section{Acknowledgements}

The authors would like to thank officials, health personnel of the two health facilities in Mendi Town for their cooperation and support during data collection. The study participants were greatly acknowledged for their willingness to participate in the study.

\section{Funding}

The study was financially supported by Jimma University.

\section{Availability of data and materials}

The data sets supporting the conclusions of this article are included within the manuscript.

\section{Authors' contributions}

YD was fully involved in all phases of the study including designing of the study, field and laboratory data collection, data analysis and write up. TK involved in supervision of the study, designing, data analysis and interpretation, and write up of manuscript for publication. Both authors read and approved the final manuscript.

\section{Competing interests}

The authors declare that they have no competing interests.

\section{Consent for publication}

Not applicable.

Ethics approval and consent to participate

The study was ethically approved by Ethical Review Committee of Jimma University, College of Natural Sciences. From all study participants, oral and written consent or assent for children $<18$ years were obtained prior to data collection; and for positive cases treatment was given according to National Malaria Diagnosis and Treatment Guidelines of Ethiopia.

Received: 3 November 2015 Accepted: 15 August 2016

Published online: 22 August 2016

\section{References}

1. WHO. World malaria report. Geneva: World Health Organization; 2008.

2. Angel SO, Mariana M, Echeverria PC. Review of recent patents on the protozoan parasite HSP90 as a drug target. Rec Pat on Biot. 2013;7:2-8.

3. Snow RW, Guerra CA, Noor AM, Myint HY, Hay SI. The global distribution of clinical episodes of Plasmodium falciparum malaria. Nature. 2005:434:214-7.

4. World Health Organization (WHO). Severe Malaria. Tropical Medicine and International Health. 2014:19(1):7-131.

5. Adhanom T, Deressa W, Witten KH, Getachew A, Seboxa T. Malaria. In: Berhane Y, Haile-Mariam D, Kloos H, editors. Epidemiology and ecology of health and disease in Ethiopia. Addis Ababa: Shama Books; 2006. p. 556-76.

6. Cheung W, Senay GB, Singh A. Trends and spatial distribution of annual and seasonal rainfall in Ethiopia. Int J Climatol. 2008;10:1002.

7. Abeku TA, van Oortmarssen GJ, Borsboom G, de Vlas SJ, Habbema JD. Spatial and temporal variations of malaria epidemic risk in Ethiopia: factors involved and implications. Acta Trop. 2003;87:331-40.

8. Negash K, Kebede A, Medhin A, Argaw D, Babaniyi O, Guintran JO, Delacollette C. Malaria epidemics in the highlands of Ethiopia. East Africa Med J. 2005:82:186-92

9. Miller LH, Mason SJ, Clyde DF, McGinniss MH. The resistance factor to $P$. vivax in blacks. The Duffy-blood-group genotype, FyFy. N Engl J Med. 1976; 295:302-4.

10. Gething PW, Patil AP, Smith DL, Guerra CA, Elyazar IR, Johnston GL, Tatem AJ, Hay SI. P. falciparum endemicity. Malar J. 2011;10:378.

11. Cavasini CE, Mattos LC, Couto AA, Bonini-Domingos CR, Valencia SH, Neiras WC, Alves RT, Rossit AR, Castilho L, Machado RL. P. vivax infection among Duffy antigen-negative individuals from the Brazilian Amazon region: an exception? Trans R Soc Trop Med Hyg. 2007;101:1042-4.

12. Poespoprodjo JR, Fobia W, Kenangalem E, Lampah DA, Hasanuddin A, Warikar N, Sugiarto P, Tjitra E, Anstey NM, Price RN. Vivax malaria: a major cause of morbidity in early infancy. Clin Infect Dis. 2009;48:1704-12.

13. Tjitra E, Anstey NM, Sugiarto P, Warikar N, Kenangalem E, Karyana M, Lampah DA, Price RN. Multidrug-resistant Plasmodium vivax associated with severe and fatal malaria, a prospective study in Papua, Indonesia. PLoS Med. 2008:5:128.

14. Kochar DK, Das A, Kochar SK, Saxena V, Sirohi P, Garg S. Severe Plasmodium vivax malaria: a report on serial cases from Bikaner in northwestern India. Am J Trop Med Hyg. 2009:80:194-8.

15. Fabbri C, de Cássia Mascarenhas-Netto R, Lalwani P, Melo GC, Magalhães BM, Alexandre MA, Lacerda MV, Lima ES. Lipid peroxidation and antioxidant enzymes activity in Plasmodium vivax malaria patients evolving with cholestatic jaundice. Mal J. 2013;12:315. 
16. Ketema T, Bacha K. Plasmodium vivax associated severe malaria complications among children in some malaria endemic areas of Ethiopia. BMC Pub Heal. 2013;13:637.

17. Price RN, von Seidlein L, Valecha N, nosten F, Baird JK, White NJ. Global extent of chloroquine-resistant Plasmodium vivax: a systematic review and meta-analysis. Lancet Infect Dis. 2014;14(10):982-991.

18. Verma P, Shukla US, Kalraiya A. Retrospective study on clinical profile of severe malaria in children admitted in a tertiary care centre of central India. People's J of Sci Res. 2014;7:22-6.

19. CSA. National statistics of central statistical agency. Ethiopia; 2007

20. World Health Organization. Guidelines for treatment of Malaria.opy. 3rd ed. Geneva; 2015

21. Cheesbrough M. District laboratory practice in tropical countries. Cambridge: Cambridge University Press; 2005. p. 24451.

22. $\mathrm{FMOH}$ (Federal ministry of Health of Ethiopia). National malaria guidelines. 3rd ed. Addis Ababa; 2012

23. Oladeinde BH, Omoregie R, Olley M, Anunibe J, Onifade A, Oladeinde O. Malaria and anemia among children in a low resource setting in Nigeria. Iranian J Parasito. 2012;7:31-7.

24. Naing C, Whittaker MA, Nyunt Wai V, Mak JW. Is Plasmodium vivax malaria a severe malaria?: A systematic review and meta-analysis. PLoS Negl Trop Dis. 2014;8(8):e3071.

25. Collins WE, Jeffery GM, Roberts JM. A retrospective examination of anemia during infection of humans with Plasmodium vivax. Am J Trop Med Hyg. 2003;68:410-41263.

26. Mahgoub H, Gasim GI, Musa IR, Adam I. Severe $P$ vivax malaria among Sudanese children at New Halfa Hospital. East Sud Para Vec. 2012:5:154.

27. Genton B, D'Acremont V, Rare L, Baea K, Reeder JC, Alpers MP. P. vivax and mixed infections are associated with severe malaria in children: a prospective cohort study from Papua New Guinea. PLoS Med. 2008;5(6):127.

28. Michon P, Cole-Tobian JL, Dabod E, Schoepflin S, Igu J, Susapu M, Tarongka N, Zimmerman PA, Reeder JC, Beeson JG, Schofield L, King CL, Mueller I. The risk of malarial infections and disease in Papua New Guinean children. Am J Trop Med Hyg. 2007;76:997-1008.

29. Anstey NM, Russell B, Yeo TW, Price RN. The pathophysiology of vivax malaria. Trends Parasitol. 2009;25:220-7.

30. Anstey NM, Douglas NM, Poespoprodjo JR, Price RN. Plasmodium vivax: clinical spectrum, risk factors and pathogenesis. Adv Parasitol. 2012;80:151-201.

31. Andrade BB, Reis-Filho A, Souza-Neto SM, Clarencio J, Camargo LM, Barral A, Barral-Netto M. Severe Plasmodium vivax malaria exhibits marked inflammatory imbalance. Malar J. 2010;9:13.

32. Jain V, Agrawal A, Singh N. Malaria in a tertiary health care facility of Central India with special reference to severe vivax: implications for malaria control. Pathog Glob Health. 2013;107:299-304.

33. Anstey NM, Handojo T, Pain MC, Kenangalem E, Tjitra E, Price RN, Maguire GP. Lung and post treatment alveolar-capillary inflammation. J Infect Dis. 2007:195(4):589-96.

34. Manning L, Laman M, Rosanas-Urgell A, Michon P, Aipit S, et al. Severe anemia in Papua New Guinean children from a malaria-endemic area: a case-control etiologic study. PLoS Negl Trop Dis. 2012;6:e1972.

35. Nurleila S, Syafruddin D, Elyazar IR, Baird JK. Serious and fatal illness associated with falciparum and vivax malaria among patients admitted to hospital at West Sumba in eastern Indonesia. Amer J of Trop Med Hyg. 2012;87:41-9.

36. Sharma R, Gohain S, Chandra J, Kumar V, Chopra A, Chatterjee S, Aneja S, Dutta AK. Plasmodium vivax malaria admissions and risk of mortality in a tertiary-care children's hospital in North India. Paediatr Int Child Health. 2012;32:152-7.

37. Olivier M, Van Den Ham K, Shio MT, Kassa FA, Fougeray S. Malarial Pigment Hemozoin and the Innate Inflammatory Response. Front Immunol. 2014:5:25

38. Parroche P, Lauw FN, Goutagny N, Latz E, Monks BG, Visintin A, Halmen KA Schumann RR. Malarial fever: Hemozoin is involved but Toll-free. PNAS. 2007; 104:1743-4.

39. Schumann RR. Malarial fever: Hemozoin is involved but Toll-free. Proc Natl Acad Sci U S A. 2007:104(6):1743-4.

40. Price RN, Douglas NM, Anstey M. Tropical and travel-associated diseases new developments in Plasmodium vivax malaria: severe disease and the rise of chloroquine resistance. Curr Opin in Infec Dis. 2009;22:430-5.

41. Luxemburger C, Thwai KL, White NJ, Webster HK, Kyle DE, Maelankirri L, Chongsuphajaisiddhi T, Nosten F. The epidemiology of malaria in a Karen population on the western border of Thailand. Trans R Soc Trop Med Hyg 1996:90:105-11.

42. Luxemburger C, Ricci F, Nosten F, Raimond D, Bathet S, White NJ. The epidemiology of severe malaria in an area of low transmission in Thailand. Trans R Soc Trop Med Hyg. 1997;91:256-62.

43. WHO. World Health Organization. Severe falciparum malaria. Trans R Soc Trop Med Hyg. 2000;94(1):S1/1-S1/90.

44. Baird JK. Evidence and implications of mortality associated with acute Plasmodium vivax malaria. Clin Microbiol Rev. 2013:26:36-57.

45. Abdallah TM, Abdeen MT, Ahmed IS, Hamdan HZ, Magzoub M, Adam I. Severe $P$. falciparum and $P$. vivax malaria among adults at Kassala Mala hospital eastern Sudan. Malaria J. 2013;12:148.

46. Lacerda MV, Mourão MP, Alexandre MA, Siqueira AM, Magalhaes BM, Martinez-Espinosa FE, Filho FS, Brasil P, Ventura AM, Tada MS, Couto VS, Silva AR, Silva RS, Alecrim MG. Understanding the clinical spectrum of complicated Plasmodium vivax malaria: a systematic review on the contributions of the Brazilian literature. Malar J. 2012;11:12.

47. Ratcliff E, Maristela R, Wuwung RM, Laihad F, Ebsworth EP, Anstey NM, Tjitra E, Price RN. Two fixed-dose artemisinin combinations for drug-resistant falciparum and vivax malaria in Papua, Indonesia: an open-label randomised comparison. Lanc. 2007;369:757-65.

48. Alexandre MA, Ferreira CO, Siqueira AM, Magalhaes BL, Mourao MP, Lacerda MV, Alecrim MG. Severe Plasmodium vivax malaria, Brazilian Amazon. Emerg Infect Dis. 2010;16:11-1614

49. Kute VB, Trivedi HL, Vanikar AV, Shah PR, Gumber MR, Patel HV, Goswami JG, Kanodia KV. Plasmodium vivax malaria associated acute kidney injury, India. Emerg Infect Dis. 2011;18:842-5.

50. Mueller I, Kaiok J, Reeder JC, Cortes A. The population structure of Plasmodium falciparum and Plasmodium vivax during an epidemic of malaria in the eastern highlands of Papua New Guinea. Am J Trop Med Hyg. 2002;67:459-64.

\section{Submit your next manuscript to BioMed Central and we will help you at every step:}

- We accept pre-submission inquiries

- Our selector tool helps you to find the most relevant journal

- We provide round the clock customer support

- Convenient online submission

- Thorough peer review

- Inclusion in PubMed and all major indexing services

- Maximum visibility for your research

Submit your manuscript at www.biomedcentral.com/submit

) Biomed Central 